\section{Lisboa, Lisbon, and the exception}

\author{
Lisboa, Lisbon e a excepção
}

Francisco Miguel VALADA (Vrije Universiteit Brussel)

Francisco.Miguel.Goncalves.Valada.Da.Silva@vub.be

Recebido em: 05 de set. de 2019. Aceito em: 14 de jan. de 2020.
VALADA, Francisco Miguel.

Lisboa, Lisbon, and the exception.

Entrepalavras, Fortaleza, v. 10, n.

1, p. 98-120, jan-abr/2020. DOI:

10.22168/2237-6321-11720.

Abstract: The graphemic form < Lisbon> in the title refers to an underlying [ 'lizbən] with a voiced heterosyllabic /zb/ cluster. Chomsky and Halle (1968, p. 150, n. 105) indicate the example Lisbon as one of the exceptions to the devoicing of obstruent clusters in English. Corresponding orthographic $<\mathrm{sb}>$ clusters in Portuguese obey a rule according to which a [3] occurs as the phonetic realization of an underlying and unspecified for voice and place of articulation /S/ that assimilates the voicing of the following consonant [b], as in Lisboa [liz'boe]. It should be borne in mind that not only are /zb/ clusters exceptional in English but that /zb/ and /sb/ may be equally licensed (as in asbestos), while the cooccurrence of voiced and voiceless segments within a cluster is not possible in Portuguese. This paper aims at obtaining answers to the following research question: do native speakers of English experience difficulties when producing Portuguese voiced sC heterosyllabic clusters, taking into account (a) the different syllable structures of these clusters in the L1 (English) and the L2 (Portuguese), and (b) the assimilation process in Portuguese, whereby if $\mathrm{C}$ is voiced in $\mathrm{SC}$, then $/ \mathrm{S} /=[3]$ ? The main conclusions 
are that assimilation seems less problematic than palatalization for native speakers of English when producing heterosyllabic word-medial Portuguese sC clusters and that individual differences may play an important role. More research is needed, with a focus on instruction and with more informants, to confirm or dismiss these conclusions.

Keywords: Phonology. Transfer. Voicing assimilation.

Resumo: A forma grafémica <Lisbon> do título refere-se a um ['lızbən] subjacente com uma sequência heterossilábica vozeada /zb/. Chomsky e Halle (1968, p. 150, n. 105) indicam o exemplo Lisbon como uma das excepções ao ensurdecimento de sequências de obstruintes em inglês. Grupos grafémicos do tipo <sb > obedecem a uma regra segundo a qual a ocorrência de [3] corresponde à realização fonética de um /S/ subjacente e não especificado que assimila o vozeamento da consoante subsequente [b], como em Lisboa [liz'boe]. Deve ter-se presente não só o carácter excepcional de sequências do tipo /zb/ em inglês, mas também quer a equivalente admissibilidade de /zb/ e /sb/, como em asbestos (amianto), quer a impossibilidade em português da presença de segmentos vozeados e surdos na mesma sequência. Este artigo procura obter resposta para a seguinte pergunta: falantes nativos de inglês terão dificuldade na produção de grupos sC heterossilábicos vozeados, tendo em conta (a) as diferentes estruturas silábicas destes grupos na L1 (inglês) e na L2 (português) e (b) o processo de assimilação em português em que se C é vozeado em sC, então $|S|=[3]$ ? Segundo as conclusões deste artigo, na produção de grupos portugueses sC mediais heterossilábicos por falantes nativos de inglês, a assimilação aparenta ser menos problemática do que a palatalização, podendo haver um papel importante desempenhado pelas diferenças individuais. É necessária mais investigação, centrada na instrução e com um maior número de informantes, para confirmar ou infirmar estas conclusões.

Palavras-chave: Assimilação de vozeamento. Fonologia. Transferência.

\section{Introduction}

The study conducted for this paper is exploratory. It is closely related to, and an obvious consequence of, another project developed elsewhere (VALADA, 2018a, 2018b), with 12 subjects: 6 native speakers of English speakers of European Portuguese as a foreign language and 6 native speakers of Portuguese speakers of English as a foreign language. Both studies are inspired by previously undertaken research (VALADA, 2017), with 30 subjects, native speakers of European Portuguese. The shift from a Portuguese as a native language perspective to a Portuguese as a second/foreign language perspective is not the only difference between these projects. Valada (2017) tried to understand how native speakers of European Portuguese behaved in terms of word-initial vowel pronunciation or suppression comparing word-initial unstressed esC forms (henceforth, esC forms), such as escola (school), which have a theoretical empty nucleus assigned to the vowel, with exC and (h)isC forms, such as extremo (extreme) and histórico (historical), which have a theoretical filled nucleus assigned to the vowel. 
V. 10 (1) 98-120 jan-abr 2020

In addition, Valada (2018a, 2018b) investigated native-like and nonnative-like pronunciation of the same forms by native speakers of English, focussing on two aspects: native-like behaviour concerning word-initial vowel, and palatalization of the fricative corresponding to $<\mathrm{s}>$ in esC and (h)isC forms and to $<\mathrm{x}>$ in exC forms.

It should be added that $\mathrm{SC}$ clusters have been overlooked and remain under-researched in second language acquisition, as testified by primary research synthetized in meta-analyses and narrative reviews that deal with effects of pronunciation instruction. For instance, among 86 studies that investigate pronunciation and instructed second language acquisition, synthesized by Lee, Jang and Plonsky's (2015) meta-analysis, Cardoso's (2010) paper is the only dealing with sC clusters.

The paper is organized as follows. A first section, entitled "sC clusters in English and Portuguese", contains a brief analysis of word-medial sC clusters in English and Portuguese, in order to identify similarities and differences in syllable structure, processes and phonological material. The second section ("a previous study") presents a research (VALADA, 2018a, 2018b) that focussed on native speakers of English producing Portuguese word-initial esC forms - escola (school), espaço (space) or estado (state) -, which served as a prototype for the current study. The third section ("the current study") describes the research in hand, presenting the participants, the methods and the results obtained. The final section ("concluding remarks") discusses the main results of this paper.

\section{sC clusters in English and Portuguese}

Similar to Chomsky and Halle (1968, p. 48, n. 105), Raffelsiefen (1999, p. 280, n. 86) presents [zb] (le [zb]ian) as an exception to the devoicing of obstruent clusters in English. According to Goman (1981, p. 107), word-initial obstruent clusters are always voiceless in English, as in spat, stop or skit, and suppression of the devoicing process only occurs medially and finally, as in Mazda [mæzdə] or used [ju:zd].

It is also important to remember that it is within the syllable that the constraint according to which all obstruent clusters are voiceless applies, although exceptions not split by a morpheme boundary do exist, such as monomorphemic adze or ides (see HOOPER, 1975, p. 538; MINKOVA, 2014, p. 135), which is different from word-ending clusters split by a morpheme boundary, such as /kses/ in sixths (see DUANMU, 
2008, p. 48; SCHEER, 2004, p. 23). It is also worth adding that English allows the resyllabification of $\mathrm{s \# g} \mathrm{(coda+onset)} \mathrm{sequences} \mathrm{into} \mathrm{\# sg}$ (onset), with a concurrent devoicing: let's go devoiced into [letskəv] (see CHURMA, 1984, p. 225; STAMPE, 1979, p. 24).

In English, it is possible for voiceless alveolar fricative /s/ to be palatalized in circumstances such as (a) when followed by prepalatal /J/ (see HOLST; NOLAN, 1995, p. 320; MINKOVA, 2014, p. 47); (b) when the word has an /r/ environment (MAJOR, 2008, p. 82); and (c) when it precedes the palatal glide /j/ (see MINKOVA, 2014, p. 47; ZSIGA, 1994, p. 67). The following sentence provides examples of the three possible $\underline{s}$ (in italic and underlined) palatalizations due to given environments (highlighted in italic and bold).

(1) Miss Sheila moved to Regent Street this year.

(1a) Mis sheila

(1b) Street

(1c) this year

Moreover, only /s/ and /s/ allow the occurrence of a phoneme other than the approximants /l, r, j, w/ as second consonant in onset position (see LORENZ, 2012, p. 97). To these elements, it is also important to add the recent occurrence in English of previously unattested word-initial clusters such as / $\mathrm{sm}-$, fl-/ [-voice/+voice] clusters (MINKOVA, 2014, p. 148-50) that differ from the long-standing stable [+voice/+voice] and [-voice/ -voice] Portuguese clusters (see EMILIANO, 2009, p. 253-255).

On the other hand, Kaye (1992) refers to word-internal $s$ spellings as being "generally" pronounced $[z]$ in "unnatural sequences", as in the cases of plasma [zm] or grisly [zl].

Analysing the syllabification of intervocalic clusters through Maximal Onset Syllabification it is important to highlight that this rule is not consistently applied when the preceding vowel is in stressed position, such as 'A.spen' or 'As.pen', 'hi.sto.ry' or 'his.to.ry', 'ma.scot 'or 'mas.cot' (see MINKOVA, 2014, p. 42-43). Moreover, according to Kaye (1992), taking into consideration empirical data, word-internal sC sequences are not syllabified like onset, overruling both the Maximum Onset Principle and the Sonority Hierarchy Principle. For instance, taking the word whisky as an example, according to Duanmu (2008, 
V. $10(1)$ 98-120 jan-abr 2020 p. 55), due to the Law of Finals and the Weight-Stress Principle, the only unambiguous and licenced syllabification is [wıs.ki]. The syllable structure of the English word whisky, according to Duanmu (2008, p. 55), can be observed in (2).

(2)

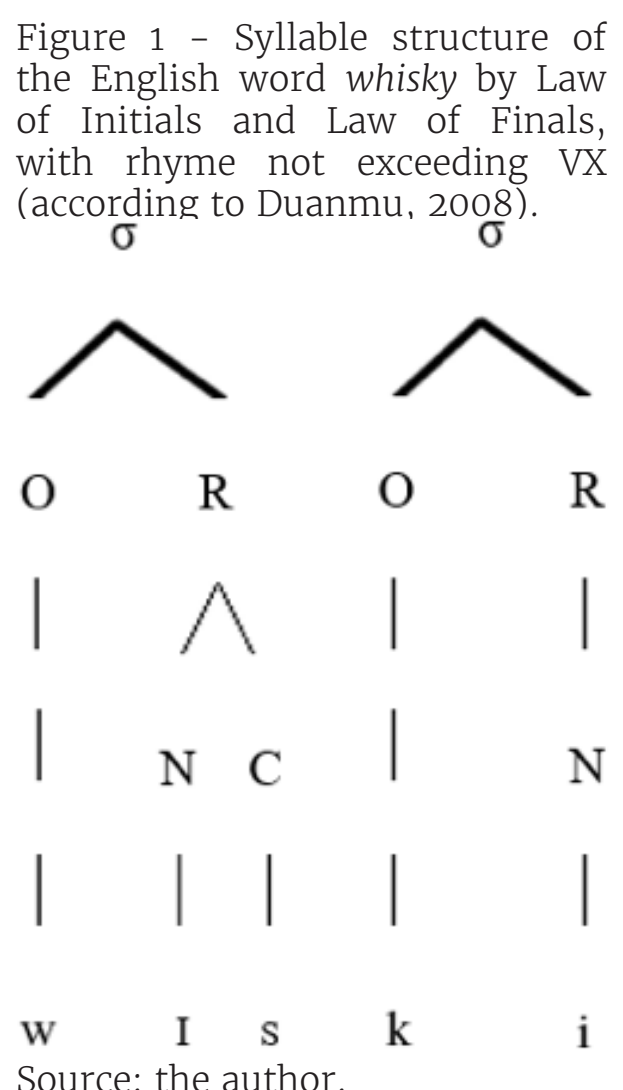

This state of affairs is compared to that of standard European Portuguese, where alveolar fricatives /s/ and / $/$ / do not occur in coda position. Instead, a prepalatal fricative occurs, voiceless both wordfinally, e.g., lápis ['la.pif] (pencil), and before voiceless consonant, e.g., galispo [ge.'lij.pu] (the northern lapwing, peewit), or becoming voiced before a voiced consonant, e.g., Lisboa [liz.'boe] (Lisbon), or a sandhi alveolar fricative /z/ may occur, when followed by word-initial vowel, resyllabified as an onset, e.g., lápis azul [,la.pij.e.'zul] $\rightarrow$ [, la. pi.ze.'zul] (blue pencil). Since /s/ and /z/ realization is - alongside the underspecified segments /R/ and /L/ - sensitive to the phonetic context (see MATEUS; D'ANDRADE, 1998), it is represented as an archiphoneme /S/ (see COLLISCHONN; WETZELS, 2016, p. 104; EMILIANO, 2009, p. 253-255; MATEUS, 1996, p. 186-189; MATEUS; D'ANDRADE, 2000, p. 52; RODRIGUES; HORA, 2016, p. 517; VILLALVA, 2008, p. 95-98). 
Comparing with the English example in (2), the same word has two realizations in Portuguese (EMILIANO, 2009): (3a) with coda /S/ due to the /i/ nucleus, and (3b) with /s/ specified for voice and place of articulation, therefore in an unstressed syllable and onset position followed by an empty nucleus in unstressed position (see FREITAS; RODRIGUES, 2003). The syllable structure of the Portuguese word uísque (whisky) is illustrated in (3a) and that of the Portuguese word whisky (whisky) in (3b).

(3) a.

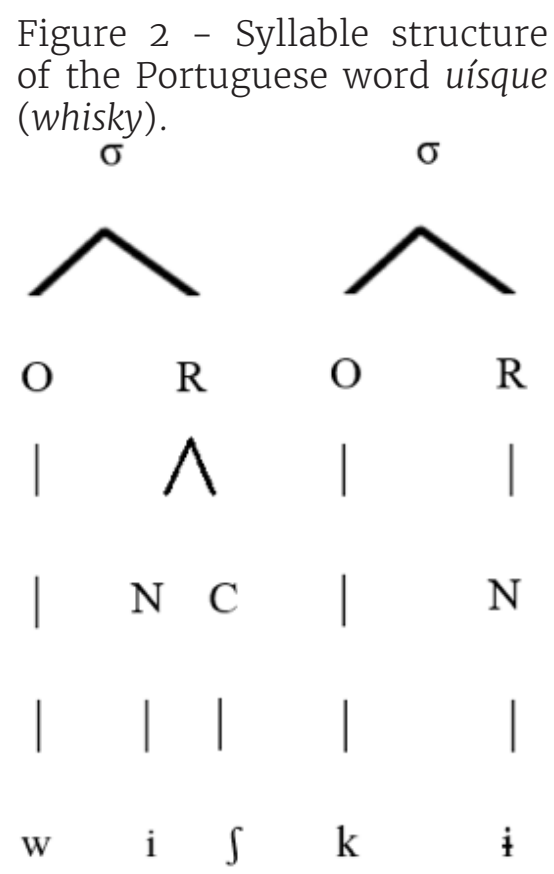

Source: the author.

b.

Figure 3 - syllable structure of the Portuguese word whisky (whisky).

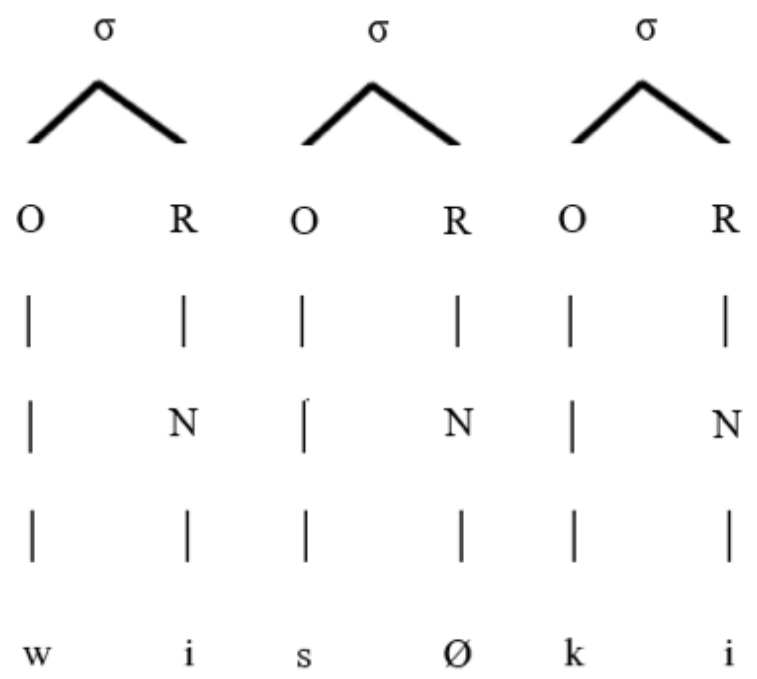

Source: the author. 
V. $10(1)$ 98-120 jan-abr 2020

As exemplified in (2) and (3), similar phonological patterns in English and Portuguese are not translated either in similar syllable structures, as exemplified in (2) and (3b), or in similar behaviour of the segments within the syllable, as exemplified in (2) and (3a).

Portuguese underspecified /S/ in coda position is translated in English by a specified /s/ or /z/ segment, not palatalized in coda position, and not following strict voicing rules, as shown by asbestos where $<\mathrm{sb}>$ can be either /zb/ or /sb/.

On the other hand, for Portuguese /S/ in coda position, English has both the phonological material [j, 3] and the processes: palatalization, as seen in (1), and a voiced [z] (though alveolar) "generally" corresponding to orthographic <s> in <sl> and <sm> clusters (see KAYE, 1992).

In European Portuguese, word-initial orthographic esC forms (for discussion, see FREITAS; RODRIGUES, 2003; HENRIQUES, 2012a, 2012b; VALADA, 2017; VELOSO, 2002) are assigned a word-initial empty nucleus, since there is no vowel production in the standard dialect, unless preceded by a negative prefix or (not necessarily) by a word-final /S/. The syllable structure of the word escola (school) is shown in (4).

(4)

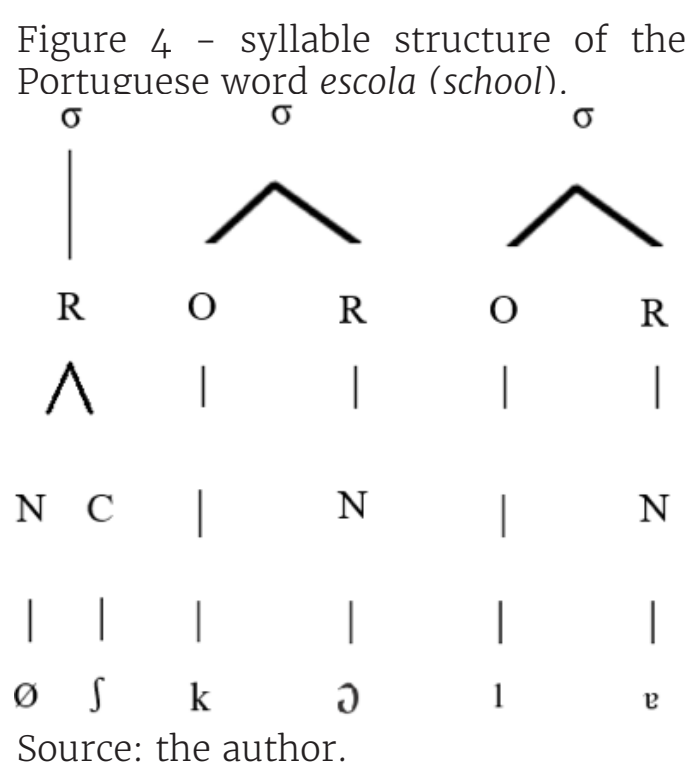

On the other hand, words with word initial orthographic exC and (h)isC forms (see FREITAS; RODRIGUES, 2003; VALADA, 2017) are assigned a word-initial filled nucleus, since there is vowel production, although this vowel can be deleted in the surface level. The tables in (5a) and (5b) illustrate the syllable structure of the words extremo (extreme) and histórico (historical), respectively. 
(5) a.

Figure 5 - syllable structure of the Portuguese word extremo (extreme).
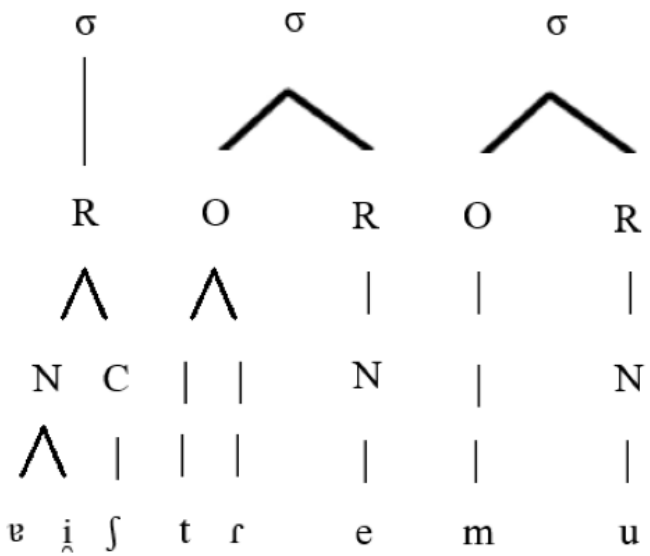

Source: the author.

b.

Figure 6: syllable structure of the Portuguese word histórico (historical).
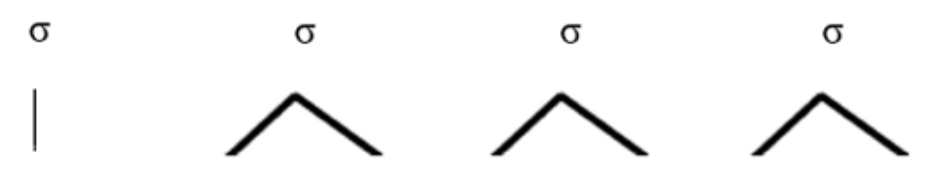
$\mathrm{R}$
O $\quad \mathrm{R} \quad \mathrm{O}$
R O
$\mathrm{R}$

105

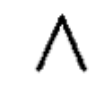

$\mathrm{N} \quad \mathrm{C}$

$\mathrm{N}$

$\mathrm{N} \quad \mathrm{I}$

$\mathrm{N}$

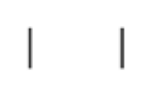

i $\int$

$\mathrm{t}$

$5 \quad r$

i k

u

Source: the author.

Words such as abstrair (to abstract as in "consider out of practical context"), with a surface form similar to the English lobster (one of the examples in CHOMSKY; HALLE, 1968, p. 150, n. 105, see also MCCAWLEY 1976, p. 153), have an empty nucleus between /b/ and /s/ (MATEUS; D'ANDRADE, 2000). The syllable structure of the word abstrair is displayed in (6). 
V. $10(1)$

$98-120$

jan-abr

2020
(6)

Figure 7: syllable structure of the Portuguese word abstrair (to abstract).

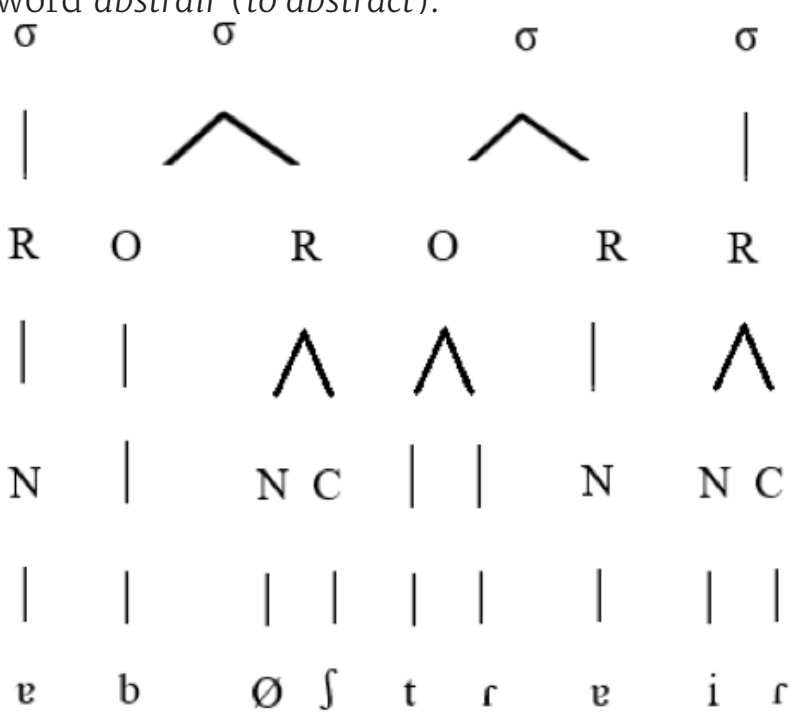

Source: the author.

\section{A previous study}

A study conducted between the end of 2017 and the beginning of 2018 (VALADA, 2018a, 2018b) tried to understand if native speakers of English were capable of native-like production of Portuguese esC, exC and (h)isC forms - e.g., escola (school); extremo (extreme); histórico (historical) -, taking into consideration word-initial vowel pronunciation or suppression and palatalization of the fricative corresponding to $<\mathrm{s}>$ in esC and (h)isC forms and to $<\mathrm{x}>$ in exC forms. The population was composed of 12 adults: a target group of 6 native speakers of English, speakers of Portuguese as L2, and a comparison group of 6 native speakers of Portuguese, speakers of English as L2. Each group was composed of 3 males and 3 females. The comparison group was intentionally composed of speakers of the standard dialect, therefore excluding possible apico-alveolar [s, z] pronunciations in coda instead of the prepalatal [ 5,3$]$ (see RODRIGUES; HORA, 2016, p. 520). The ages of the informants ranged between $29 ; 6.18$ and $55 ; 2.19^{1}$, at the time of the experiment. All subjects worked in Belgium as conference interpreters for the institutions of the $\mathrm{EU}$ (simultaneous interpreters have excellent phonological memory: see O'BRIEN et al., 2007). 
Corpus 1

An oral questionnaire-interview was administered to both groups in English and replies were given in Portuguese. Questions included keywords to elicit forms with patterns. Native-like performance was based on analysis of word-initial vowel production or suppression, /S/ surfacing as a prepalatal [s, 3], and /S/ assimilating the voicing of $C$ (for details see EMILIANO, 2009; FREITAS; RODRIGUES, 2003; VALADA, 2017).

The corpus obtained from the questionnaire was subject to acoustic analysis with Praat software (BOERSMA; WEENINK, 2010). The table in (7) gives an overview of the results for the target population, with (+) native-like and (-) nonnative-like, broken down by informant (ENF1-3 and ENM1-3), and pattern.

(7)

Table 1 - Informants' production of Portuguese esC, exC and (h)isC forms

\begin{tabular}{|c|c|c|c|c|c|c|c|c|}
\hline & \multicolumn{2}{|c|}{ esC /S/ } & \multicolumn{2}{|c|}{ exC /S/ } & \multicolumn{2}{c|}{ (h)isC /S/ } & \multicolumn{2}{|c|}{ TOTAL } \\
\hline$+/-$ & + & - & + & - & + & - & + & - \\
\hline ENF1 & 5 & 3 & 1 & 1 & 3 & & 9 & 4 \\
\hline ENF2 & 9 & & 4 & & 1 & & 14 & 0 \\
\hline ENF3 & 8 & & 5 & & 2 & & 15 & 0 \\
\hline ENM1 & 33 & 5 & 2 & & 5 & & 40 & 5 \\
\hline ENM2 & 20 & 1 & 1 & & & & 21 & 1 \\
\hline ENM3 & 26 & & 12 & & 3 & & 41 & 0 \\
\hline
\end{tabular}

It should be noted that, for the comparison group of 6 native speakers of Portuguese (PTF1-3 and PTM1-3), lack of palatalization occurred twice. The occurrences were identified (similarly to the case of ENM2 below) as isolated instances (included in the dataset), with sporadic, non-systematic articulatory misproductions. All informants of the target population had more positive (native-like) results than negative (nonnative); three informants (ENF2, ENF3 and ENM3) outperformed the rest of the target group, with all tokens /S/ corresponding to a prepalatal, while a fourth informant (ENM2) only had one token (among 22 tokens) without palatalization, identified as an isolated instance (also included in the dataset): only two informants (ENF1 and ENM1) clearly underperformed, but with more positive than negative results. 
V. $10(1)$ $98-120$ jan-abr 2020

Since results differ in palatalization, depending on whether the form has empty (esC) or filled (exC and (h)isC) nucleus, a second corpus was extracted, using data from the same oral questionnaireinterview.

\section{Corpus 2}

This corpus was obtained from the same set of answers used for corpus 1. After the hypothesis that the status of the nucleus might influence palatalization, corpus 2 was created with all word-medial sC forms. Since these have a filled nucleus, there is common ground for comparison with exC and (h)isC forms: see (5a) and (5b). This exercise allowed the addition of assimilation to the study. In Valada (2018a, 2018b), there was no occurrence where C corresponded to voiced consonant, therefore assimilation could not be studied.

The table in (8) illustrates spontaneous production of all word-medial $\mathrm{sC}$ clusters (other than exC and hisC forms) by the same target group. No problems were detected for the comparison group. The table is broken down by informant, by pattern - $/ \mathrm{S} /+\mathrm{C}[+$ voice $]$, e.g., mesmo (same); /S/+C[-voice], e.g., isto (this, neuter) -, and by subsets - palatalization and assimilation. Although voiced [3] (or even [z]) is not expected in $/ \mathrm{S} /+\mathrm{C}[-$-voice $]$, columns were kept, in order to include unforeseen occurrences of a voiced fricative. A value 0.5 was assigned to the native-likeness $(+)$ or nonnative-likeness $(-)$ of each token, in order to integrate the two criteria/processes, yielding a result in the total column mirroring the exact overall number of tokens.

(8)

Table 2 - Informants' production of Portuguese word-medial sC clusters

\begin{tabular}{|c|c|c|c|c|c|c|c|c|c|c|}
\hline \multirow[b]{3}{*}{$+/-$} & \multicolumn{4}{|c|}{$/ \mathrm{S} /+\mathrm{C}[+$ voice $]$} & \multicolumn{4}{|c|}{$/ \mathrm{S} /+\mathrm{C}[$-voice $]$} & & \\
\hline & \multicolumn{2}{|c|}{ palat } & \multicolumn{2}{|c|}{ assim } & \multicolumn{2}{|c|}{ palat } & \multicolumn{2}{|c|}{ assim } & \multicolumn{2}{|c|}{ TOTAL } \\
\hline & + & - & + & - & + & - & + & - & + & - \\
\hline ENF1 & 0.5 & & 0.5 & & 3.5 & 1 & 4.5 & & 9 & 1 \\
\hline ENF2 & 0.5 & & 0.5 & & 1.5 & & 1.5 & & 4 & \\
\hline ENF3 & & & & & 1 & & 1 & & 2 & \\
\hline ENM1 & & & & & 1 & & 1 & & 2 & \\
\hline ENM2 & 0.5 & & 0.5 & & 5 & & 5 & & 11 & \\
\hline ENM3 & & & & & 7.5 & & 7.5 & & 15 & \\
\hline
\end{tabular}

Source: the author. 
Only one informant (ENF1) had difficulties producing all /S/ as a prepalatal fricative: the only underperformer for exC forms in (7). Overall, there seems to be no difficulty for native speakers of English to produce Portuguese word-medial sC clusters. This confirms the global results from (7). Therefore, a new study was needed, with a special focus on voiced word-medial sC clusters, since there were only 3 occurrences of tokens with this pattern.

\section{The current study}

Based on the concluding remarks from subsection corpus 2, another study was specifically designed to obtain an answer to the research question presented in the abstract: do native speakers of English experience difficulties when producing Portuguese voiced $\mathrm{sC}$ heterosyllabic clusters?

Participants

Subjects were 2 conference interpreters, 1 male (ENM1) and 1 female (ENF1), with ages 38;7.30 and 35;1.7, respectively, at the time of the recordings. Both were native speakers of English, L2 speakers of European Portuguese, selected from a population of 6 native speakers of English that had participated, together with a comparison group of 6 native speakers of Portuguese, in the experiments of Valada (2018a, 2018b) (see the second section, "a previous study"). These 2 participants were the underperformers in native-likeness of prepalatal production in (7), albeit with positive global results.

Materials

To assess the participants' native-like production of voiceless and voiced prepalatal fricatives in word-medial sC clusters, tokens with the following word-medial patterns were ideally pre-selected for the present study. Therefore, the following words are not necessarily part of the corpus, but constitute examples of words with relevant patterns for the current study:

(9)/s/+obstruent: 3b transbordar (to overflow), ,p transportar (to transport); 3d desde (since); ft teste (test); $3 g$ rasgar (to tear, rip); jk mascar (to chew); 3V desvantagem (disadvantage); jf blasfémia (blasphemy); js fascismo (fascism); zz deszelar (to neglect); 33 disjuntor (circuit-breaker); 
V. 10 (1) 98-120 jan-abr 2020 (10)/s/+sonorant: 3m abismo (abyss); 3n asneira (nonsense/ blunder); 31 deslocar (to move, dislocate); 3R desrespeito (disrespect).

Although the ultimate goal of this paper is related to Portuguese words graphemically similar to the English words asbestos, husband, and Presbyterian (see CHOMSKY; HALLE, 1968, p. 150, n. 105), i.e., with voiced obstruent clusters, the corpus also includes obstruent+sonorant - where /S/ is voiced, as in (10) - and voiceless obstruents, to retest the palatalization.

From three corpora consulted (CRPC, 2012; DAVIES; FERREIRA, 2012; DAVIES; PRETO-BAY, 2008), it is clear that words with wordmedial voiced clusters like Lisboa (Lisbon), desde (since), desgraça (tragedy), desvio (diversion), Cisjordânia (West Bank), mesmo (same), legislação (legislation), Israel (Israel) are very frequent in Portuguese - for instance, words such as mesmo (same, $39^{\text {th }}$ place) and desde (since, $135^{\text {th }}$ place), have a prominent position among the top 5000 most frequent words in Portuguese.

The corpus of the current study does not include wordinitial esC forms, with graphemic <e> in unstressed position, already studied both in first language (L1) (VALADA, 2017) and second language (L2) (VALADA, 2018a, 2018b) perspectives. This exclusion is due to possible bias when producing fricatives following a word-initial empty nucleus, a status traditionally assigned to these forms (see MATEUS; D'ANDRADE, 2000). Therefore, words with an empty nucleus such as abstrair (to abstract as in "consider out of practical context"), abstenção (abstention), etc. - see (6) above - are also accordingly excluded. On the other hand, this study includes exC and (h)isC forms, e.g., extremo (extreme) and histórico (historical), patterns with filled nucleus - see (5a) and (5b) -, although these may have surface behaviour similar to esC forms, see Valada (2017).

In addition to word-medial clusters, word-boundary clusters had also been selected, with examples such as [ff] word-boundary voiceless cluster Uma das pessoas mais famosas do mundo (One of the most famous people in the world); or word-boundary voiced cluster [3v] muitas vezes (often). However, since a word-final voiceless fricative is also possible in cases where a word-initial voiced consonant follows, namely when a pause occurs at a word boundary, these tokens were excluded from subsequent analysis. 
Procedure and analysis

The procedure is very similar to the one adopted for subsection corpus 1. In order to obtain data from spontaneous speech, participants were asked in Portuguese about their opinion on a few subjects, such as, for example, differences between Lisbon and Oporto or between concepts with word-ending -ism (communism, fascism, etc.). The ultimate purpose was to obtain word-medial sC cluster tokens with [3] before voiced consonant, as /s/+obstruent Lisboa or /s/+sonorant word-ending -ismo, as comunismo and fascismo. The corpus was complemented with other (spontaneous) word-medial sC cluster tokens with [3] before voiced consonant. Some words were not considered as spontaneous, namely those that, despite not being directly elicited, were morphologically similar words. However, as stated before, the elicited/ spontaneous division was not considered as a criterion for analysis.

As in Valada (2018a; 2018b), the researcher (a native speaker of European Portuguese and L2 speaker of English) asked the questions in English to avoid any direct influence/contamination from his Portuguese pronunciation.

After a total of $23 \mathrm{mo} 4 \mathrm{~s}$ (1384s) of recorded conversation 7m38s (478s) for ENF1 and 15m26s (926s) for ENM1 -, 93 tokens were obtained from ENF1 (28) and ENM1 (65): 34 word-medial voiceless clusters (15 for ENF1 and 19 for ENM1) and 59 word-medial voiced clusters (13 for ENF1 and 46 for ENM1). It should be noted that, within this context, token is clearly distinct from word: for example, the word fascista [fa]'sifte] (fascist) has two /S/ $\rightarrow[5]$ tokens, extremismo [(ei) ftri'mizmu]) (extremism) has one $/ \mathrm{S} / \rightarrow[\mathrm{S}]$ token and one $/ \mathrm{S} / \rightarrow[\mathbf{3}]$ token, while islamismo [izle'mizmu] (Islamism) has two $/ \mathrm{S} / \rightarrow[\mathbf{3}]$ tokens.

This corpus was extracted from the oral questionnaire/ interview, and the data displayed in (11) and (12) show the patterns obtained. It is clear that not all 15 patterns identified in (9) and (10) were extracted: 7 patterns ( $3 \mathrm{~b}, 5 \mathrm{p}, 3 \mathrm{~d}$, $\mathrm{st}, \mathrm{s}, 3 \mathrm{~m}, 3 \mathrm{l}$ ) were obtained from ENF1 and ENM1, while 8 (3g, 5k, 3V, ff, 3Z, 33, 3n, 3R) were not. Indeed, the table in (14) contains 9 patterns instead of 7 , since the occurrences of [sk] and of [3R] - respectively, desconhecida (unknown, f.) and Israel (Israel) - from a member of the comparison group (PTF2) are explicitly indicated as productions of a native speaker of Portuguese, and they were kept in the table for possible future analysis. 
V. $10(1)$ $98-120$ jan-abr 2020 (11)/s/+obstruent: 3b Lisboa (Lisbon), sp explicar (to explain); 3d (desde since); jt isto (this, neuter); js fascismo (fascism);

(12) /s/+sonorant: 3m comunismo (communism); 3l islâmico (Islamic).

Indeed, no specific comparison or control group was created for this particular task, since it was considered that data from corpus 1 could be used as comparison. Therefore, from the 6 native speakers of Portuguese informants of corpus 1, data from PTF2 and PTM2 were used, since these were the subjects with more tokens. At first, PTF2 and PTM1 had been selected as the best candidates, since both had had a sporadic lack of palatalization in the previous study (see the second section, "a previous study"), which would place them in the ideal "underperformer" position. However, PTM1 only had one token with word-medial voiced sC cluster - simplesmente (simply) -, which was not considered enough for the eligibility of that informant. Therefore, PTM2 was selected instead of PTM1, due to the number of tokens. The patterns of the sub-corpus, obtained from spontaneous and semielicited production of Portuguese word-medial voiced and voiceless $\mathrm{SC}$ clusters, are displayed in (14), broken down by informant (ENF1, ENM1. PTF2 and PTM2), with (+) meaning a native-like realization and (-) meaning a nonnative-like realization.

Acoustic analysis of the utterances was performed, and examples displayed in $(13 \mathrm{a}-\mathrm{c})$ serve to illustrate the $(+)$ and $(-)$ values assigned in (14). The spectrogram in (13a) illustrates a production of comunismo (communism) by ENF1. Where [3] was expected, noise is shown in very high frequencies (above $3500 \mathrm{~Hz}$ ), with a [z] instead of [3], that in (14) has received a $0.5(+)$ for assimilation but a $0.5(-)$ for palatalization. There were no occurrences of [s] instead of [3]. In (13b) another production of comunismo (communism) occurs, this time by ENM1: there is a [3], the expected native-like production, extending down to $2000 \mathrm{~Hz}$, and it has been assigned a $0.5(+)$ for assimilation and a $0.5(+)$ for palatalization. Finally, in (13c), a production of islamismo (Islamism) by ENM1, with [s] instead of [3], also extending down to approximately 200ohz, occurs; it was assigned a $0.5(-)$ for assimilation but a $0.5(+)$ for palatalization - the difference can be perceived by the lack of a voicing bar, if compared both to the misproduction of (13b) and to the [3] corresponding to /S/ in <sl> in (13C) itself. 
(13) a.

Figure 8 - Spectrogram of comunismo (communism) by ENF1

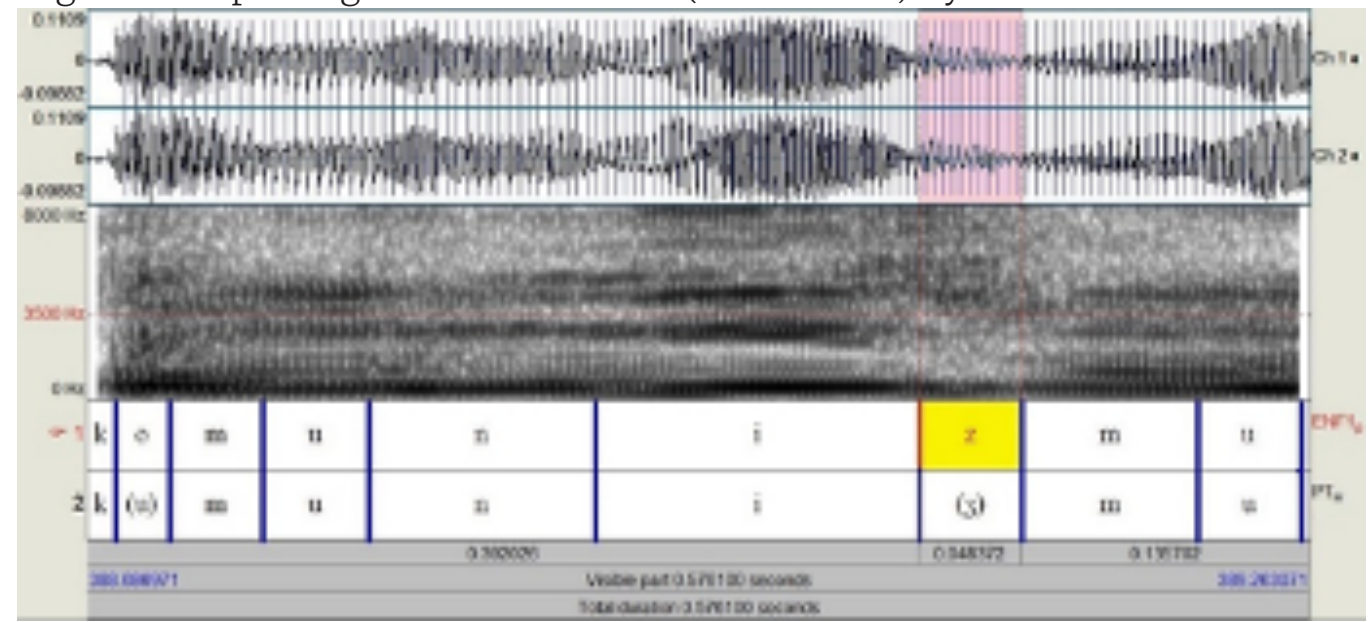

Source: the author.

b.

Figure 9 - Spectrogram of comunismo (communism) by ENM1

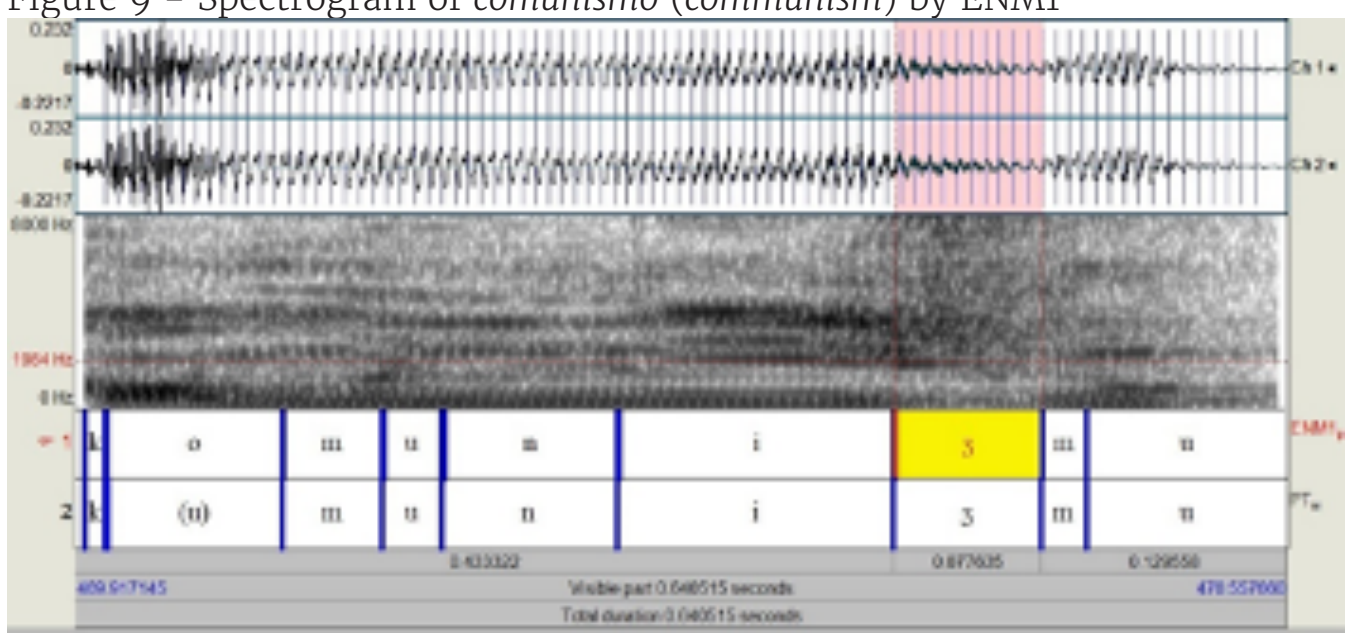

Source: the author.

C.

Figure 10 - Spectrogram of islamismo (Islamism) by ENM1

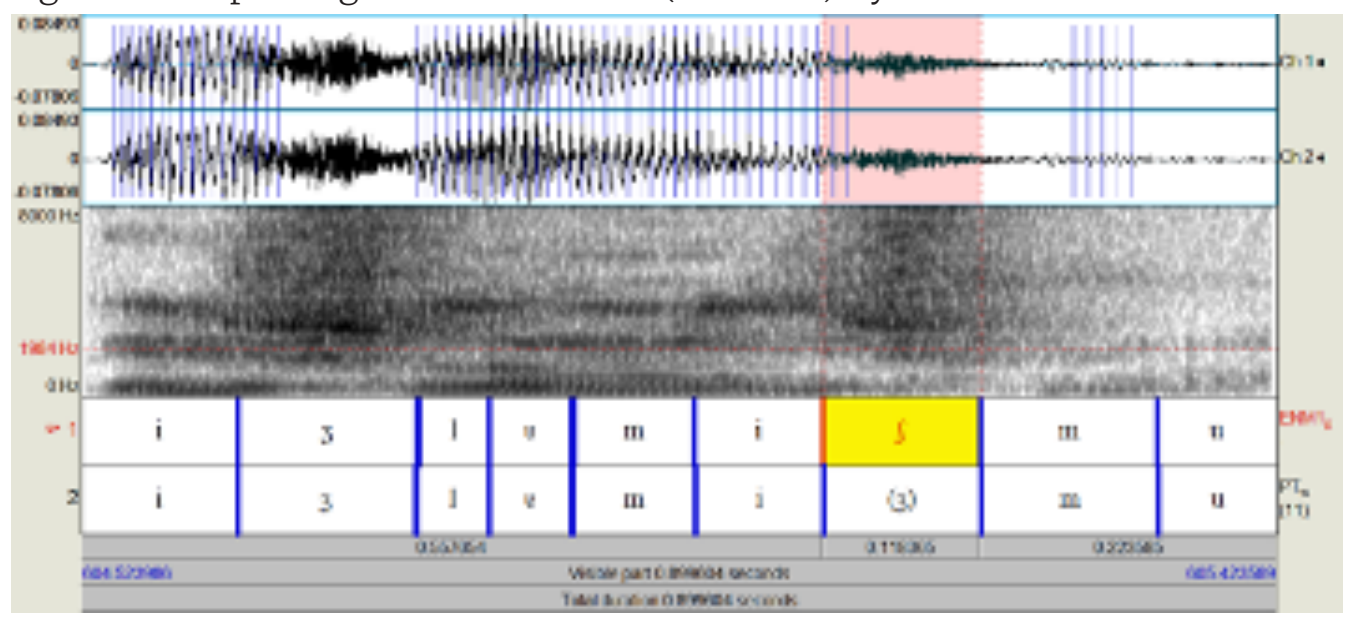

Source: the author. 
V. 10 (1) 98-120 jan-abr 2020

(14)

Table 3 - palatalization and assimilation patterns of Portuguese word-medial sC clusters by target (experimental) and comparison groups

\begin{tabular}{|c|c|c|c|c|c|c|c|c|c|c|c|c|c|c|c|c|}
\hline & \multicolumn{4}{|c|}{ ENF1 } & \multicolumn{4}{|c|}{ ENM1 } & \multicolumn{4}{|c|}{ PTF2 } & \multicolumn{4}{|c|}{ PTM2 } \\
\hline & \multicolumn{2}{|c|}{ palat. } & \multicolumn{2}{|c|}{ assim. } & \multicolumn{2}{|c|}{ palat. } & \multicolumn{2}{|c|}{ assim. } & \multicolumn{2}{|c|}{ palat. } & \multicolumn{2}{|c|}{ assim. } & \multicolumn{2}{|c|}{ palat. } & \multicolumn{2}{|c|}{ assim. } \\
\hline & + & - & + & - & + & - & + & - & + & - & + & - & + & - & + & - \\
\hline [3b] & 0.5 & 0 & 0.5 & 0 & 9.5 & 0 & 9.5 & 0 & 0 & 0 & 0 & 0 & 0 & 0 & 0 & 0 \\
\hline [3m] & 0.5 & 4.5 & 5 & 0 & 10 & 0 & 9 & 1 & 2.5 & 0 & 2.5 & 0 & 1.5 & 0 & 1.5 & 0 \\
\hline [31] & 0 & 0.5 & 0.5 & 0 & 3.5 & 0 & 3.5 & 0 & 0 & 0 & 0 & 0 & 0 & 0 & 0 & 0 \\
\hline [3d] & 0.5 & 0 & 0.5 & 0 & 0 & 0 & 0 & 0 & 0 & 0 & 0 & 0 & 0 & 0 & 0 & 0 \\
\hline [3R] & 0 & 0 & 0 & 0 & 0 & 0 & 0 & 0 & 0.5 & 0 & 0.5 & 0 & 0 & 0 & 0 & 0 \\
\hline$\left[\int \mathrm{t}\right]$ & 4.5 & 1.5 & 6 & 0 & 6.5 & 1 & 7.5 & 0 & 8 & 0 & 8 & 0 & 6 & 0 & 6 & 0 \\
\hline [sp] & 0.5 & 0 & 0.5 & 0 & 0 & 0 & 0 & 0 & 3 & 0 & 3 & 0 & 1 & 0 & 1 & 0 \\
\hline$\left[\int \mathrm{s}\right]$ & 0 & 1 & 1 & 0 & 1.5 & 0.5 & 2 & 0 & 0 & 0 & 0 & 0 & 0 & 0 & 0 & 0 \\
\hline [ $[\mathrm{k}]$ & 0 & 0 & 0 & 0 & 0 & 0 & 0 & 0 & 0.5 & 0 & 0.5 & 0 & 0 & 0 & 0 & 0 \\
\hline
\end{tabular}

Source: the author.

As in (8), a value 0.5 was assigned to the native-likeness (+) or nonnative-likeness (-) of each token, in order to integrate palatalization and assimilation, obtaining a total result that reflects the exact overall number of tokens.

A first conclusion from the table in (14) is that both informants from the comparison group had $100 \%$ positive results, without (even if sporadic, non-systematic) articulatory misproductions, as those previously identified in (7).

Focussing on the target population (ENF1 and ENM1), the pattern [3b] has 100\% native-like pronunciations for both subjects. However, despite the elicitation of Lisbon, ENF1 only uttered the corresponding Lisboa once - in turn, ENM1 had 19 tokens: 17 Lisboa and 2 lisboetas (a native or inhabitant of Lisbon, pl.). For the pattern [3m], ENF1 had no issues concerning assimilation, however palatalization did not occur in nine tokens or, in other words, the expected [3m] only occurred once in ten productions, while $*[\mathrm{zm}]$ occurred nine times. In turn, lack of assimilation occurred twice for ENM1- islamismo (Islamism) *[izle'mifmu] instead of [izle'mizmu] - see (13c) -, and realismo (realism) $*$ [Rje'lifmu] instead of [Rje'lizmu]. For the pattern [3l], the only token, by ENF1, was islâmico (Islamic) with [zl], therefore assimilation was not problematic, but palatalization was. In turn, 
informant ENM1 had native-like productions for his 7 [3l] tokens. ENF1 had native-like production in her only [3d] token: desde (since) - no [3d] data for ENM1.

Considering /S/+[-voice] patterns, no issues on assimilation were detected (in any case, the 0.5 factor was maintained for homogeneity in the performance review). The pattern [jt] was problematic due to lack of palatalization in a fourth of ENF1's productions (3 in 12): cristianismo (Christianity), extremismo (extremism), and *romanticisto (romanticism). This last word is non-existent in Portuguese; however, it was kept due to the production of the pattern: as stated in the conclusions, the criterion named "native-likeness" (vs. nonnative-likeness) in this paper is word-medial sC specific and does not translate overall proficiency. In turn, ENM1's nonpalatalization production was slightly higher than an eighth (2 tokens in 15, i.e., 13\%). The pattern [sp] only occurred once and for ENF1 with palatalization: explicar (to explain). The two tokens with the pattern [ss] in ENF1's sub-corpus - two occurrences of fascismo (fascism) - were problematic in terms of palatalization, while only a fourth of ENM1's production - one occurrence of fascista (fascist), among two other occurrences of fascista and an occurrence of cresci (to grow up, 1sg.past.) -, had lack of palatalization.

\section{Conclusions}

The first conclusion from the table in (8) was that only one informant (ENF2) seemed to have difficulties in producing 100\% of /S/ as a prepalatal fricative. Such nonnative-like production was expected due to the underperformance for exC forms, as displayed in (7). It should be underlined that, for the purposes of this paper, "native-likeness" vs. "nonnative-likeness" only takes into account the target features studied, i.e, the concept is word-medial sC specific. The acceptance of words that are a result of transfer, such as *romanticismo (instead of romantismo, for English romanticism), and the lack of analysis of non-native pronunciations such as [o] instead of [u] in comunismo (communism) i.e. *[komu'nizmu] instead of [kumu'nizmu] -, for both ENF1 (13a) and ENM1 (13b), emphasises this point. It should also be added that for the case of *romanticismo there was immediate indirect corrective feedback by the researcher, instructing in English that there was one ci too many.

Another important aspect is the imbalance between ENF1 and ENM1, already noted in (7), though not so much in (8). From the only pattern under analysis that allows sound conclusions, i.e., 
V. $10(1)$ $98-120$ jan-abr 2020 [3m], it is clear that ENF1 continues to be the underperformer, both in palatalization and assimilation. This fact, linked to the lack of sufficient data (3 tokens) from (8) justified this new study, since at first glance it seemed that palatalization would not be a problem for ENF1.

Therefore, two main conclusions can be drawn from [3m] in (14):

(1) It cannot be stated that native speakers of English experience major difficulties when producing Portuguese voiced sC heterosyllabic clusters, considering data from ENM1;

(2) Previous and current data from ENF1 leave open the hypothesis that individual cases should probably be treated separately, since there is a disparity in terms of proficiency between this subject and, not only ENM1, but all other 5 subjects previously studied.

\section{Concluding remarks}

The first conclusion is that assimilation is less problematic than palatalization for native speakers of English when producing heterosyllabic word-medial Portuguese sC clusters. The second conclusion is that palatalization does not always occur, a circumstance that had already been identified in (7). As in (7), informant ENF1 underperformed in palatalization when compared to ENM1 and there were cases where negative (nonnative) results prevailed for ENF1, but never for ENM1. The fact that only one informant significantly outperformed leaves still open the question whether individual differences, that is, aptitude, intelligence, working memory or attention capacity (see e.g. LEVKINA; GILABERT, 2012, p. 193) are the cause of the lack of proficiency, and whether drawing attention to the specific differences between L1 and L2, with form-focussed instruction (see SPADA, 1997, p. 73), is an adequate answer for ENF1 to overcome her difficulties with these features.

For instance, although palatalization seems problematic, it occurs even among informants where negative results are occasionally predominant. This may imply that it is a surmountable difficulty. This also suggests that native speakers of English speakers of Portuguese may improve their fluency, by learning and producing [3] for /S/ before voiced consonant with a focus on instruction. 
According to data in (14), namely from [3m], the exceptional character of the devoicing of obstruent clusters in English, the different syllable structures of word-medial sC clusters in Portuguese and English, and the different realizations of Portuguese /S/ before voiced and voiceless consonants do not hinder the global production of native-like Portuguese tokens by a native speaker of English. On the one hand, systematicity without explicit instruction may be problematic, since the results are not similar to PTF2 and PTM2. On the other, the problems identified do not seem unsurmountable. However, differences between ENF1 and ENM1, previously detected by the results from the second section ("a previous study"), may suggest that individual differences play a role in the native-likeness of these productions.

Other studies are necessary, with a statistically relevant population, and not restricted to two informants. Future analyses should include an important section devoted to the roles of meaningful exposure, implicit instruction and explicit instruction. The effects of instruction on the acquisition of these phonological features in a second language were only considered as possibly relevant for this project during the final stages of the study.

Another aspect has to do with elicitation: data from spontaneous speech should be complemented with reading-aloud exercises, in order to obtain a larger number of tokens, allowing a more balanced quantitative data analysis between subjects and a full range of patterns. Although the overall result (voiced and voiceless clusters altogether) seems to confirm the conclusions from Valada (2018a, 2018b), the fact that ENF1 only had one token for voiced patterns [3b, 3l, 3d] and that ENM1 did not have tokens for the [3d] pattern left only one voiced cluster [3m] fit for analysis, bearing in mind the main purpose of this paper.

After the work with similar patterns with native speakers of Portuguese (VALADA, 2017), this project focussed on a Portuguese as a foreign language perspective, and managed to identify methodological hurdles, paving the way for an in-depth analysis of the issue, in order to confirm or dismiss these first conclusions.

I would like to thank Alex Chabot, Bastien De Clercq, Guillaume Enguehard, David Hardisty, Alex Housen, Oihane Muxika-Loitzate, Denise Osborne and Tobias Scheer for their very useful comments and suggestions. My thanks also go to the anonymous reviewers for their constructive analyses. And finally, my thanks go to the 12 subjects who made Valada (2018a, 2018b) possible, and, last but not least, to the 2 subjects from that previous study that made this paper a reality. 
V. 10 (1) $98-120$ jan-abr 2020

118

\section{References}

BOERSMA, Paul; WEENINK, David. Praat: Doing Phonetics by Computer. Computer program, version 6.0.22, 2010. Available at: <http://www.praat. org/>. Accessed: August 9, 2018.

CARDOSO, Walcir. Teaching foreign sC onset clusters: Comparing the effects of three types of instruction. In: Proceedings of the Sixth International Symposium on the Acquisition of Second Language Speech New Sounds. Poznań: Adam Mickiewicz University, 2010. p. 61-66.

CHOMSKY Noam; HALLE, Morris. The Sound Pattern of English. New York: Harper \& Row, 1968.

CHURMA, Donald G. Impossible nativizations as phonological evidence and the explanation of constraints of phonological structure. Journal of Linguistics, $\mathrm{v}$. 30, p. 223-227, 1984.

COLLISCHONN, Gisela; WETZELS, W. Leo. Syllable Structure. In: COSTA, João; MENUZZI, Sergio M.; WETZELS, W. Leo (Eds.). The Handbook of Portuguese Linguistics. Hoboken, NJ: Wiley-Blackwell, 2016. p. 86-106.

CRPC. Corpus de Referência do Português Contemporâneo. Centro de Linguística da Universidade de Lisboa (CLUL), 2012. Available at: <http:// www.clul.ulisboa.pt/en/10-research/713-crpc-reference-corpus-ofcontemporary-portuguese $>$. Accessed: September 28, 2018.

DAVIES, Mark; FERREIRA, Michael. Corpus do Português NOW, 2012-. Available at: <https://www.corpusdoportugues.org/now/>. Accessed: June 24, 2018

DAVIES, Mark; PRETO-BAY, Ana Maria. A Frequency Dictionary of Portuguese. New York/London: Routledge, 2007.

DUANMU, San. Syllable Structure: The limits of variation. Oxford: Oxford University Press, 2008.

EMILIANO, António. Fonética do Português Europeu. Lisboa: Guimarães, 2009.

FREITAS, Maria João; RODRIGUES, Maria Celeste. On the nature of sC-clusters in European Portuguese. Journal of Portuguese Linguistics, v. 2, n. 2, p. 55$85,2003$.

GOMAN, Roderick D. On the natural phonology of consonants. Ohio State University Working Papers in Linguistics, v. 25, p. 107-173, 1981.

HENRIQUES, Isabel. The Production and the Syllabic Nature of Word Initial sC-Clusters in European Portuguese Speakers. Corela [online], HS11, 2012a. Available at: <http://journals.openedition.org/corela/2660>. Accessed: June $24,2018$.

HENRIQUES, Isabel. A Fricativa Coronal /S/ em /\#( $\emptyset)$ SC/ em Português Europeu (Unpublished doctoral dissertation). Porto: Universidade do Porto, 2012b. 
HOLST, Tara; NOLAN, Francis. The influence of syntactic structure on [s] to [S] assimilation. In: CONNELL, Bruce; ARVANITI, Amalia (Eds.). Phonology and Phonetic Evidence: Papers in Laboratory Phonology IV. Cambridge: Cambridge University Press, 1995. p. 315-333.

HOOPER, Joan. B. The archi-segment in natural generative phonology. Language, V. 51, p. 536-560, 1975.

KAYE, Jonathan. Do you believe in magic? The story of $\mathrm{s}+\mathrm{C}$ sequences. SOAS Working Papers in Linguistics, v. 2, p. 293-313, 1992.

LEE, Junkyu; JANG, Juhyun; PLONSKY, Luke. The effectiveness of second language pronunciation instruction: A meta-analysis. Applied Linguistics, v. 36, n. 3, p. 345-366, 2015.

LEVKINA, Mayya; GILABERT, Roger. The effects of cognitive task complexity on L2 oral production. In: HOUSEN, Alex; FOLKERT, Kuiken; VEDDER, Ineke (Eds.). Dimensions of L2 performance and proficiency: Complexity, accuracy, and fluency in SLA. Amsterdam: Benjamins, 2012. p. 171-198.

LORENZ, Frank. Basics of Phonetics and English Phonology. Berlin: Logos Verlag, 2012.

MAJOR, Roy C. Transfer in second language phonology: A review. In: EDWARDS, J. G. H.; ZAMPINI, Mary L. (Eds.). Phonology and Second Language Acquisition. Amsterdam/Philadelphia: John Benjamins, 2008. p. 63-94.

MATEUS, M. H. M. Fonologia. In: FARIA, Isabel Hub et al. (Eds.). Introdução à Linguística Geral e Portuguesa. Lisboa: Caminho, 1996. p. 171-199.

MATEUS, M. H. M.; D'ANDRADE, E. The syllable structure in European Portuguese. DELTA, v. 14, p. 13-32, 1998.

MATEUS, M. H. M.; D'ANDRADE, E. The Phonology of Portuguese. Oxford: Oxford University Press, 2000.

MCCAWLEY, James D. Review of Chomsky and Halle, The Sound Pattern of English. In: GOYVAERTS, Didier; PULLUM, Geoffrey K. (Eds.). Essays on the Sound Pattern of English. Ghent: Story-Scientia, 1976. p. 145-97.

MINKOVA, Donka. A Historical Phonology of English. Edinburgh: Edinburgh University Press, 2014.

O'BRIEN, Irena et al. Phonological memory predicts second language oral fluency gains in adults. Studies in Second Language Acquisition, v. 29, p. 557-581, 2007.

RAFFELSIEFEN, Renate. Phonological constraints on English word formation. In: BOOIJ, Geert; VAN MARLE, Jaap (Eds.). Yearbook of Morphology 1998. Dordrecht: Kluwer, 1999. p. 225-287.

RODRIGUES, Maria Celeste; HORA, Dermeval da. Main current processes of phonological variation. In: COSTA, João; MENUZZI, Sergio M.; WETZELS, W. Leo (Eds.). The Handbook of Portuguese Linguistics. Hoboken, NJ: WileyBlackwell, 2016. p. 504-525. 
V. $10(1)$ 98-120 jan-abr 2020

SCHEER, Tobias. A lateral theory of phonology. Vol. 1: What is CVCV, and why should it be? Berlin \& New York: Mouton de Gruyter, 2004.

SPADA, Nina. Form-focussed instruction and second language acquisition: A review of classroom and laboratory research. Language Teaching, v. 29, p. 73-87, 1997.

VALADA, Francisco M. Portuguese words that begin with the written form "es+consonant": do they have a prothetic vowel? (Unpublished master's thesis). Brussels: Vrije Universiteit Brussel, 2017.

VALADA, Francisco M. Portuguese Phonology and Native Speakers of English: Exponent, Excoriation, History and Spontaneity. Paper presented at Current Approaches to Spanish and Portuguese Second Language Phonology (CASPSLaP 2018), Indiana University, Bloomington, IN, February, 2018a.

VALADA, Francisco M. Portuguese esC, exC and (h)isC forms revisited: theory and data. Paper presented at Contemporary Research in Phonetics and Phonology: Methods, Aspects and Problems (CRiPaP 2018), University of Latvia, May, 2018b.

VELOSO, João. Do fricative+plosive onsets exist word-initially in European Portuguese? In: PETROVA, Krasimira; EFTIMOVA, Andreana; SHOPOV, Radko (Eds.). Litora psycholinguistica. Sofia: Sema RSH, 2002. p. 49-56.

VILLALVA, Alina. Morfologia do Português. Lisboa: Universidade Aberta, 2008.

ZSIGA, Elizabeth C. An acoustic and electropalatographic study of lexical and post-lexical palatalization in American English. Haskins Laboratories Status Report on Speech Research, SR, V. 117/118, p. 6779,1994 . 